\title{
Evaluation of Traditional Indian Antidiabetic Medicinal Plants for Human Pancreatic Amylase Inhibitory Effect In Vitro
}

\author{
Sudha Ponnusamy, ${ }^{1}$ Remya Ravindran, ${ }^{2}$ Smita Zinjarde, ${ }^{1}$ Shobha Bhargava, ${ }^{3}$ \\ and Ameeta Ravi Kumar ${ }^{1}$ \\ ${ }^{1}$ Institute of Bioinformatics and Biotechnology, University of Pune, Ganeshkhind, Pune 411007, India \\ ${ }^{2}$ School of Biotechnology, Amrita Vishwa Vidyapeetham, Kollam, Kerala 690525, India \\ ${ }^{3}$ Department of Zoology, Molecular Embryology Laboratory, University of Pune, Pune 411007, India
}

Correspondence should be addressed to Ameeta Ravi Kumar, ameeta@unipune.ernet.in

Received 19 May 2010; Accepted 7 August 2010

Copyright (C) 2011 Sudha Ponnusamy et al. This is an open access article distributed under the Creative Commons Attribution License, which permits unrestricted use, distribution, and reproduction in any medium, provided the original work is properly cited.

Pancreatic $\alpha$-amylase inhibitors offer an effective strategy to lower the levels of post prandial hyperglycemia via control of starch breakdown. Eleven Ayurvedic Indian medicinal plants with known hypoglycemic properties were subjected to sequential solvent extraction and tested for $\alpha$-amylase inhibition, in order to assess and evaluate their inhibitory potential on pancreatic $\alpha$-amylase. Analysis of 91 extracts, showed that 10 exhibited strong Human Pancreatic Amylase (HPA) inhibitory potential. Of these, 6 extracts showed concentration dependent inhibition with $\mathrm{IC}_{50}$ values, namely, cold and hot water extracts from Ficus bengalensis bark (4.4 and $125 \mu \mathrm{gmL}^{-1}$ ), Syzygium cumini seeds $\left(42.1\right.$ and $4.1 \mu \mathrm{gmL}^{-1}$ ), isopropanol extracts of Cinnamomum verum leaves $\left(1.0 \mu \mathrm{gmL}^{-1}\right)$ and Curcuma longa rhizome $\left(0.16 \mu \mathrm{gmL}^{-1}\right)$. The other 4 extracts exhibited concentration independent inhibition, namely, methanol extract of Bixa orellana leaves $\left(49 \mu \mathrm{gmL}^{-1}\right)$, isopropanol extract from Murraya koenigii leaves $\left(127 \mu \mathrm{gmL}{ }^{-1}\right)$, acetone extracts from $C$. longa rhizome $\left(7.4 \mu \mathrm{gmL}^{-1}\right)$ and Tribulus terrestris seeds $\left(511 \mu \mathrm{gmL}^{-1}\right)$. Thus, the probable mechanism of action of the above fractions is due to their inhibitory action on HPA, thereby reducing the rate of starch hydrolysis leading to lowered glucose levels. Phytochemical analysis revealed the presence of alkaloids, proteins, tannins, cardiac glycosides, flavonoids, saponins and steroids as probable inhibitory compounds.

\section{Introduction}

Diabetes mellitus is a carbohydrate metabolism disorder of endocrine system due to an absolute or relative deficiency of insulin secretion, action, or both [1]. The disorder affects more than 100 million people worldwide and by 2030 it is predicted to reach 366 million. The most prevalent form both in the global and Indian scenario is the noninsulin dependent diabetes mellitus (NIDDM type 2) which is associated with elevated postprandial hyperglycemia [2].

Pancreatic $\alpha$-amylase (E.C. 3.2.1.1), is a key enzyme in the digestive system and catalyses the initial step in hydrolysis of starch to maltose and finally to glucose. Degradation of this dietary starch proceeds rapidly and leads to elevated post prandial hyperglycemia (PPHG). It has been shown that activity of Human Pancreatic $\alpha$-amylase (HPA) in the small intestine correlates to an increase in post-prandial glucose levels, the control of which is therefore an important aspect in treatment of diabetes [3]. Hence retardation of starch digestion by inhibition of enzymes such as $\alpha$ amylase would play a key role in the control of diabetes. However, the discovery of specific high-affinity inhibitors of pancreatic $\alpha$-amylase for the development of therapeutics has remained elusive. Inhibitors currently in clinical, use for example, acarbose, miglitol, and voglibose, are known to inhibit a wide range of glycosidases such as $\alpha$-glucosidase and $\alpha$-amylase. Because of their nonspecificity in targeting different glycosidases, these hypoglycemic agents have their limitations and are known to produce serious side effects. Therefore, the search for more safer, specific, and effective hypoglycemic agents has continued to be an important area of investigation with natural extracts from readily available traditional medicinal plants offering great potential for discovery of new antidiabetic drugs $[4,5]$.

While plant derivatives with purported hypoglycemic properties have been used in folk medicine and traditional 
healing systems, very few of these traditional anti-diabetic plants have received proper scientific or medical scrutiny despite recommendations by World Health Organization (WHO). Ayurveda and other Indian traditional approaches have described more than 800 plants in the Indian subcontinent, known to possess antidiabetic potential. These require to be effectively studied and in fact only few of them have been characterized for their mechanistic actions [6-9]. Plants such as Barringtonia racemosa, Phyllanthus amarus, and so forth, have been tested for the presence of pancreatic $\alpha$ amylase inhibitors from various regions of the world [1015]. Most of them have been tested on porcine pancreatic $\alpha$ amylase (PPA) and salivary amylase while reports on their effect on human pancreatic amylase (HPA), if any, are scarce.

In this study, we have selected medicinal plants from the Indian Ayurvedic system with known hypoglycemic or antidiabetic activity, in an attempt to screen for new inhibitors for HPA. The selections of these plants were based on their traditional usage and also taking into consideration previous studies that have demonstrated their antidiabetic properties (Table 1), thus providing a preliminary screening assessment [16-26]. However, no known reports of these plants as HPA inhibitors exist. Sequential solvent extracts of Azadirachta indica A. Juss., Bixa orellana L., Bougainvillea spectabilis Willd., Cinnamomum verum J. S. Presl, Curcuma longa L., Ficus bengalensis L., Ficus racemosa L., Momordica charantia L., Murraya koenigii L. Spreng., Syzygium cumini L. Skeels, and Tribulus terrestris L. were tested for the presence of PPA and HPA inhibitors. The lead extracts have also been subjected to preliminary kinetics on HPA to ascertain the type of inhibition as well as for phytochemical analysis to determine the probable inhibitory compounds present.

\section{Methods}

2.1. Chemicals. Starch, porcine pancreatic $\alpha$-amylase (PPA), methanol, isopropanol, acetone, methyl-butyl-tertiary ether, cyclohexane, and dimethylsulfoxide (DMSO) were purchased from SRL Pvt. Ltd, Mumbai, India. 3,5-dinitrosalicylicacid (DNSA) was obtained from HiMedia Laboratories, Mumbai, India. Human pancreatic $\alpha$-amylase (HPA) and acarbose were purchased from Sigma Aldrich, USA. All other chemicals procured were from local manufacturer and were of AR grade.

2.2. Plant Material. In this study, anti-diabetic plants from the Indian sub-continent were selected on the basis of known ethno botanical/traditional Ayurvedic literature. Plants were obtained from Pune city and nearby areas of the Western Ghats, India, in the months of August-January. The plants, their voucher numbers (V. No.), the part(s) used, and the hypoglycemic properties as seen from literature search are listed in Table 1. A specimen of each plant was submitted to Botanical Survey of India (BSI), Pune, India, for authentication. The plants were separated into their various parts, namely., roots, stem, leaves, seeds and so forth, washed with tap water, air-dried in shade, and processed immediately as mentioned below.
2.3. Preparation of Plant Extracts. The air-dried plant material $(60-100 \mathrm{~g})$ was crushed with liquid nitrogen, powdered, and successively extracted in polar to nonpolar solvent on an increasing degree of non-polarity [27]. The different extracts obtained sequentially were with cold water, hot water, methanol, isopropanol, acetone, methyl-butyl-tertiary ether, and cyclohexane. This kind of sequential extraction was performed taking into consideration the fact that traditional methods of preparing herbal formulations are mainly aqueous. Also, aqueous extracts contain peptides, proteins, or glycans, which would otherwise be denatured by organic solvents and high-temperature extraction. Distilled water was added to the crushed material in a ratio of $1: 4$ $(\mathrm{w} / \mathrm{v})$ and kept at $30^{\circ} \mathrm{C}(24 \mathrm{~h})$ and $55^{\circ} \mathrm{C}(2 \mathrm{~h})$ at $130 \mathrm{rpm}$ for cold-and hot-water extracts, respectively. For each solvent, the extract was filtered, centrifuged, and the residue collected for subsequent solvent extraction. The organic solvents were added in a ratio of $1: 3(\mathrm{w} / \mathrm{v})$ and refluxed with the residue for $3 \mathrm{~h}$ at their respective boiling temperatures. Each extract was filtered and stored at $-20^{\circ} \mathrm{C}$.

2.4. $\alpha$-Amylase Inhibition and Kinetic Studies. PPA was used for preliminary screening of $\alpha$-amylase inhibitors from the extracts. The inhibition assay was performed using the chromogenic DNSA method [28]. The total assay mixture composed of $500 \mu \mathrm{L}$ of $0.02 \mathrm{M}$ sodium phosphate buffer ( $\mathrm{pH} 6.9$ containing $6 \mathrm{mM}$ sodium chloride), 0.04 units of PPA solution, and extracts at concentration from $0.1-$ $1.5 \mathrm{mg} \mathrm{mL}^{-1}(\mathrm{w} / \mathrm{v})$ were incubated at $37^{\circ} \mathrm{C}$ for $10 \mathrm{~min}$. After pre-incubation, $500 \mu \mathrm{L}$ of $1 \%(\mathrm{v} / \mathrm{v})$ starch solution in the above buffer was added to each tube and incubated at $37^{\circ} \mathrm{C}$ for $15 \mathrm{~min}$. The reaction was terminated with $1.0 \mathrm{~mL}$ DNSA reagent, placed in boiling water bath for $5 \mathrm{~min}$, cooled to room temperature, diluted, and the absorbance measured at $540 \mathrm{~nm}$. The control reaction representing 100\% enzyme activity did not contain any plant extract. To eliminate the absorbance produced by plant extract, appropriate extract controls were also included. One unit of enzyme activity is defined as the amount of enzyme required to release one micromole of maltose from starch per min under the assay conditions.

For the determination of the inhibitor concentration at which $50 \%$ inhibition of enzyme activity occurs $\left(\mathrm{IC}_{50}\right)$, the assay was performed as above except that the inhibitor/plant extract concentrations were varied from $0.1-150 \mu \mathrm{g}$. Acarbose was used as a positive control at a concentration range of $6.5 \mu \mathrm{g}-32.8 \mu \mathrm{g}$. The $\mathrm{IC}_{50}$ values were determined from plots of percent inhibition versus log inhibitor concentration and calculated by logarithmic regression analysis from the mean inhibitory values. The $\mathrm{IC}_{50}$ values were defined as the concentration of the extract, containing the $\alpha$-amylase inhibitor that inhibited $50 \%$ of the PPA or HPA activity. Other quantifiers were defined as follows:

$\%$ Relative enzyme activity $=$ (enzyme activity of test/enzyme activity of control) $* 100$;

$\%$ inhibition in the $\alpha$-amylase activity $=(100-\%$ relative enzyme activity).

For kinetic experiments involving concentration independent inhibition, the inhibitor/extracts were taken at their 
TABLE 1: Plant sources and their traditional uses.

\begin{tabular}{|c|c|c|c|c|c|}
\hline Plants name $\mathrm{a}^{\mathrm{a}}$ & V. no ${ }^{\mathrm{b}}$ & Family & Parts used & Hypoglycemic and medicinal properties & Ref. \\
\hline $\begin{array}{l}\text { Azadirachta indica } \\
\text { A. Juss. (Neem) }\end{array}$ & GMAI3 & Meliaceae & Leaves & $\begin{array}{l}\text { Antihyperglycemic activity, increase in glucose } \\
\text { uptake and glycogen deposition, inhibits activity } \\
\text { of epinephrine on glucose metabolism resulting } \\
\text { in utilization of peripheral glucose. Does not alter } \\
\text { cortisol concentration. }\end{array}$ & {$[17,18]$} \\
\hline $\begin{array}{l}\text { Bixa orellana } L . \\
\text { (Sindhuri) }\end{array}$ & BOSP1 & Bixaceae & Leaves & $\begin{array}{l}\text { Hypoglycemic activity by lowering blood glucose } \\
\text { by stimulating peripheral utilization of glucose. }\end{array}$ & [19] \\
\hline $\begin{array}{l}\text { Bougainvillea } \\
\text { spectabilis Willd. } \\
\text { (Bougainvilla) }\end{array}$ & MARCKBS2 & Nyctaginaceae & Leaves & $\begin{array}{l}\text { Hypoglycemic effect is by D-pinitol which exerts } \\
\text { insulin-like effect and inhibits } \alpha \text {-glucosidase. }\end{array}$ & {$[20]$} \\
\hline $\begin{array}{l}\text { Cinnamomum } \\
\text { verum J.S.Presl } \\
\text { (Cinnamon) }\end{array}$ & CIZYS1 & Lauraceae & Leaves & $\begin{array}{l}\text { Hypoglycemic activity is by enhancing insulin } \\
\text { activity, increasing lipid metabolism and } \\
\text { antioxidant status, capillary function. }\end{array}$ & [21] \\
\hline $\begin{array}{l}\text { Curcuma longa L. } \\
\text { (Turmeric) }\end{array}$ & SUCL1 & Zingiberaceae & Rhizome & $\begin{array}{l}\text { Hypoglycemic, hypolipidemic, and antioxidant } \\
\text { property. Decreased influx of glucose in polyol } \\
\text { pathway, increasing NADPH/NADP ratio and } \\
\text { increased activity of glucose peroxidase. }\end{array}$ & {$[22]$} \\
\hline $\begin{array}{l}\text { Ficus bengalensis } L . \\
\text { (Banyan) }\end{array}$ & GMFB1 & Moraceae & $\begin{array}{l}\text { Leaves, } \\
\text { Bark }\end{array}$ & $\begin{array}{l}\text { Stimulates insulin secretion from beta cells } \\
\text { inhibits insulin degradative process. }\end{array}$ & {$[23]$} \\
\hline $\begin{array}{l}\text { Ficus recemosa } L . \\
\text { (Umbar) }\end{array}$ & GMFR2 & Moraceae & Fruit pulp & $\begin{array}{l}\text { Hypoglycemic activity by } \beta \text {-sitosterol isolated was } \\
\text { found to lower the blood glucose level. }\end{array}$ & {$[24]$} \\
\hline $\begin{array}{l}\text { Momordica } \\
\text { charantia L. } \\
\text { (Karela,) } \\
\text { (Bitter gourd) }\end{array}$ & MARCK1 & Cucurbitaceae & $\begin{array}{l}\text { Leaves, } \\
\text { fruit, seeds }\end{array}$ & $\begin{array}{l}\text { Hypoglycemic effect by inhibition of } \\
\text { glucose-6-phosphatase and } \\
\text { fructose-1-6-biphosphatase in liver and } \\
\text { stimulation of hepatic glucose-6-phosphate } \\
\text { dehydrogenase. }\end{array}$ & {$[25]$} \\
\hline $\begin{array}{l}\text { Murraya koenigii L. } \\
\text { Spreng } \\
\text { (Curry Leaves) }\end{array}$ & SP-2 & Rutaceae & Leaves & $\begin{array}{l}\text { Increases glucogenesis and decreases } \\
\text { glycogenolysis and gluconeogenesis. }\end{array}$ & [26] \\
\hline $\begin{array}{l}\text { Syzygium cumini L. } \\
\text { Skeels (Jamun) }\end{array}$ & SPSC2 & Myrtaceae & Seeds & $\begin{array}{l}\text { Reduces blood glucose level, increase in serum } \\
\text { insulin level, exhibits insulinase activity. } \\
\text { Hypoglycemic activity mediated through insulin } \\
\text { release mechanism, glycogen content and hepatic } \\
\text { glucokinase, hexokinase, glucose-6-phosphate, } \\
\text { and phosphofructokinase levels in diabetic mice. }\end{array}$ & {$[4,17]$} \\
\hline $\begin{array}{l}\text { Tribulus terrestris } \\
\text { L. (Gokshura) }\end{array}$ & SUTT1 & Zygophyllaceae & Seeds & $\begin{array}{l}\text { Hypoglycemic activity by inhibiting oxidative } \\
\text { stress. }\end{array}$ & {$[16]$} \\
\hline
\end{tabular}

a The common Indian name for the plant is given in brackets.

${ }^{b}$ Voucher numbers as given by Botanical Survey of India, Pune.

$\mathrm{IC}_{50}$ values and incubated with HPA while the substrate (starch) concentration was varied from $0.5-5 \mathrm{mg} \mathrm{mL}^{-1}$ and reaction allowed to proceed as mentioned above. Kinetic analysis was performed based on Lineweaver-Burk double reciprocal plots and the kinetic parameters calculated using Origin 6.0 software from Originlab, USA.

2.5. Preliminary Phytochemical Analysis. Qualitative phytochemical analyses of the extracts were performed according to Parekh and Chanda [29]. Alkaloids were detected by
Mayer's reagent, while for cardiac glycosides the KellerKiliani test was carried out. Steroids were detected using the Liebermann-Burchard test. Bradford reagent was used to detect the proteins while the frothing test was used for detection of saponins.

2.6. GCMS Analyses. Analyses of the organic extracts exhibiting $\geq 50 \%$ inhibition on the PPA or HPA activity were performed on a GCMS-MS (Varian 4000) gas chromatograph equipped with DB $5 \mathrm{~ms}$ capillary column 
$(30 \mathrm{~m} \times 0.25 \mathrm{~mm}$ ID). Helium was the carrier gas with flow rate of $1 \mathrm{~mL} / \mathrm{min}$, the injector mode-split $(1: 60)$, the injection volume $1 \mu \mathrm{L}$, the temperature program used is as follows: $50^{\circ} \mathrm{C}(3 \mathrm{~min})$, then increased to $280^{\circ} \mathrm{C}$ at $15^{\circ} \mathrm{C} / \mathrm{min}$, held at $280^{\circ} \mathrm{C}(10 \mathrm{~min})$ and temperature scan, $\mathrm{m} / \mathrm{z}$ 35-800. Appropriate solvent controls were also run. The identification of the components was based on the comparison of their mass spectra with those of NIST-Wiley 2008 library.

2.7. Statistical Analysis. All experiments were performed in 3 different sets, with each set in triplicates. The data are expressed as mean \pm SEM. Statistical analysis was performed for analysis of variance (ANOVA) followed by $F$ test using SPSS 11.5. Those $P$-values $\leq .05$ were considered as significant.

\section{Results}

3.1. Screening of Plant Extracts on $\alpha$-Amylase Inhibition. The plants from the Indian sub-continent exhibiting potential hypoglycemic properties were sequentially extracted with polar to non-polar solvents and a total of 91 extracts obtained. It should be noted that while generally coldand hot-water extracts are most commonly used in the traditional method of preparing medicines in Ayurveda, chances of missing out on bioactive principles with better amylase inhibitory potential from less-polar solvents are high. Hence the rationale for performing extractions from polar to non-polar solvents is not only to confirm and validate the inhibitory activity, if found, in any of the aqueous extractions performed in the traditional manner but also to search for newer and higher specific affinity inhibitors in less-polar solvents. PPA was used as a target enzyme for screening of inhibitory activity from the above mentioned ninety-one plant extracts. The control reaction representing $100 \%$ enzyme activity was $0.21 \mathrm{U} / \mathrm{mL}$ for PPA and $0.25 \mathrm{U} / \mathrm{mL}$ for HPA. Extract samples dissolved in DMSO contained as a final yield of $1.5 \mathrm{mg} \mathrm{mL}^{-1}$ of the dried extract and the enzyme activity of both PPA and HPA was not affected by DMSO at the concentration used. Appropriately diluted plant extract was used for enzyme inhibition assay and the activity obtained with each extract was normalized to percent relative activity (Figure 1) from which the percent inhibition was calculated. Less than 50\% PPA inhibition was observed for extracts of A. indica (leaves), B. spectabilis (leaves), F. bengalensis (leaves), $F$. racemosa (fruit), $M$. charantia (leaves, fruit, and seeds) as well as for extracts of MTBE and cyclohexane. Some of the extracts were found to marginally activate PPA. Of the rest, 12 extracts exhibited significant inhibition $(\geq 50 \%)$ on PPA enzyme activity. The most significant inhibitory activity was obtained with the aqueous extracts of $F$. bengalensis bark $\left(0.38 \mathrm{mg} \mathrm{mL}^{-1}\right.$ and $0.14 \mathrm{mg} \mathrm{mL}^{-1}$ for cold and hot water, resp.), $S$. cumini $\left(0.38 \mathrm{mg} \mathrm{mL}^{-1}\right.$ and $0.13 \mathrm{mg} \mathrm{mL}^{-1}$ for cold and hot water), methanol extracts of $B$. orellana $\left(0.04 \mathrm{mg} \mathrm{mL}^{-1}\right)$, C.longa $\left(1.5 \mathrm{mg} \mathrm{mL}^{-1}\right)$, C. verum $\left(2.23 \mathrm{mg} \mathrm{mL}^{-1}\right)$, isopropanol extracts of $C$. longa $\left(0.01 \mathrm{mg} \mathrm{mL}^{-1}\right)$, C. verum $\left(0.06 \mathrm{mg} \mathrm{mL}^{-1}\right)$, M. koenigi $\left(0.05 \mathrm{mg} \mathrm{mL}^{-1}\right)$ and acetone extracts of C. longa $\left(0.02 \mathrm{mg} \mathrm{mL}^{-1}\right)$ and $T$. terrestris $\left(0.33 \mathrm{mg} \mathrm{mL}^{-1}\right)$. On checking the stability of these extracts over a period of time, all the extracts except for $C$. verum methanol extract were stable even after a period of two months. Thus, further experiments were carried out with 11 stable extracts (excluding C. verum methanol extract) exhibiting PPA inhibition $\geq 50 \%$. These extracts exhibited significant inhibition $(P \leq .05)$ with $\mathrm{IC}_{50}$ values ranging between 10 and $920 \mu \mathrm{gmL}^{-1}$. C. longa and M. koenigii isopropanol extracts and S. cumini cold water extract showed the best $\mathrm{IC}_{50}$ value of $10 \mu \mathrm{gmL}^{-1}$ against PPA. The known PPA inhibitor, acarbose, taken as a positive control exhibited an $\mathrm{IC}_{50}$ value of $10.2 \mu \mathrm{gmL}^{-1}$. Those extracts exhibiting $\geq 50 \%$ inhibition for PPA were taken as lead extracts and were further tested for inhibition studies against HPA.

3.2. Extracts Exhibiting $\geq 50 \%$ Inhibition on Human Pancreatic Amylase (HPA) Activity. Of the 11 lead extracts obtained, C. longa methanol extract was not tested against HPA since the concentration required for inhibiting PPA $\left(920 \mu \mathrm{gmL}^{-1}\right)$ was high. For the other 10 extracts, differing $\mathrm{IC}_{50}$ values were obtained for HPA as compared to PPA, with values ranging from $0.16 \mu \mathrm{gmL}^{-1}$ to $511 \mu \mathrm{gmL}^{-1}$ (Figure 2). Of these, $B$. orellana methanol extract and $F$. bengalensis hotwater extract showed similar $\mathrm{IC}_{50}$ values for $\mathrm{HPA}$ as seen for PPA, while M. koenigii isopropanol, S. cumini coldwater, and $T$. terrestris acetone extracts required higher concentrations for 50\% HPA inhibition as compared to PPA. However, five extracts, namely, isopropanol extracts of $C$. longa $\mathrm{l}\left(0.16 \mu \mathrm{gmL}^{-1}\right)$ and $C$. verum $\left(1.0 \mu \mathrm{gmL}^{-1}\right)$, coldwater extract of $F$. bengalensis $\left(4.4 \mu \mathrm{gmL}^{-1}\right)$, and hot-water extracts of S. cumini $\left(4.1 \mu \mathrm{gmL}^{-1}\right)$ could inhibit HPA at much lower concentrations than PPA. Acarbose inhibited HPA with an $\mathrm{IC}_{50}$ value of $10.5 \mu \mathrm{gmL}^{-1}$. Thus, these crude extracts could inhibit HPA at much lower concentrations than even acarbose and would therefore be good candidates to test for high-affinity inhibitors. For this, inhibitor kinetic studies were performed to determine the type of inhibition.

3.3. Kinetic Studies. The inhibitory assays were performed using extracts at different dilutions in order to check for concentration dependent or independent inhibition. Of the 10 plant extracts studied, 6 extracts, namely, C. longa (isopropanol), C. verum (isopropanol), F. bengalensis (cold and hot water), and S. cumini (cold and hot water) exhibited concentration dependent (competitive) inhibition. Plots of percent inhibition versus log concentration (Figure 3) of extracts showed typical sigmoidal dose response curves with $50 \%$ inhibition at concentrations $0.16 \mu \mathrm{gmL}^{-1}, 1.0 \mu \mathrm{gmL}^{-1}$, $4.4 \mu \mathrm{gmL}^{-1}, 125 \mu \mathrm{gmL}^{-1}, 42.1 \mu \mathrm{gmL}^{-1}$, and $4.1 \mu \mathrm{gmL}^{-1}$, respectively, for HPA. The lowest $\mathrm{IC}_{50}$ value for HPA was noted for $C$. longa isopropanol extract at $0.16 \mu \mathrm{gmL}^{-1}$. Many of these extracts were found to competitively inhibit HPA at much lower concentrations than the commercially used inhibitor acarbose $\left(10.5 \mu \mathrm{gmL}^{-1}\right)$.

On the other hand, 4 extracts, namely, B. orellana (methanol), C. longa (acetone), M. koenigii, (isopropanol), and T. terrestris L. (acetone) extracts exhibited concentration 


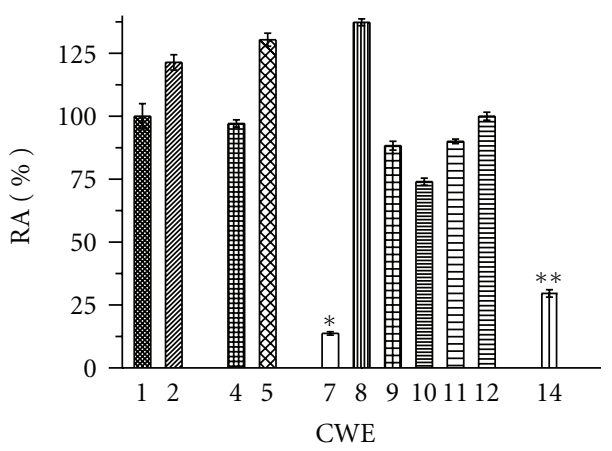

(a)

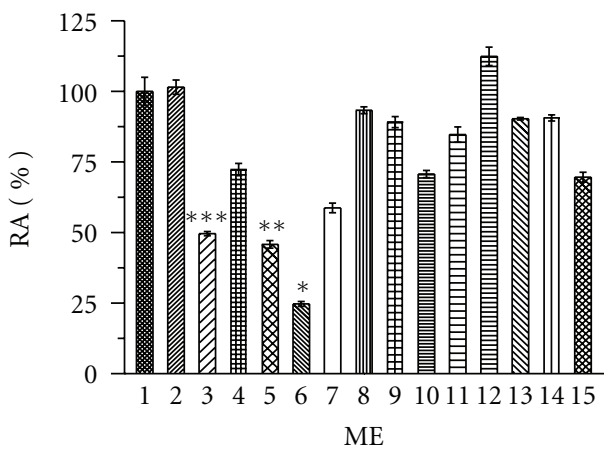

(c)

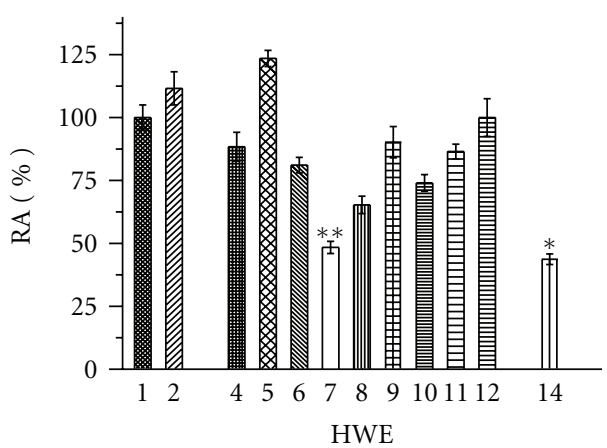

(b)

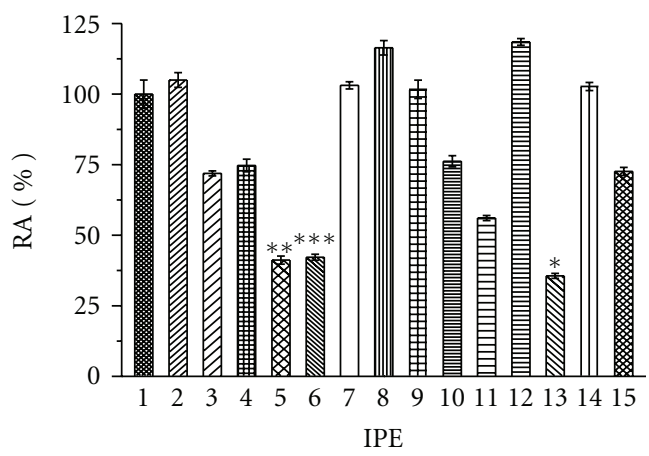

(d)
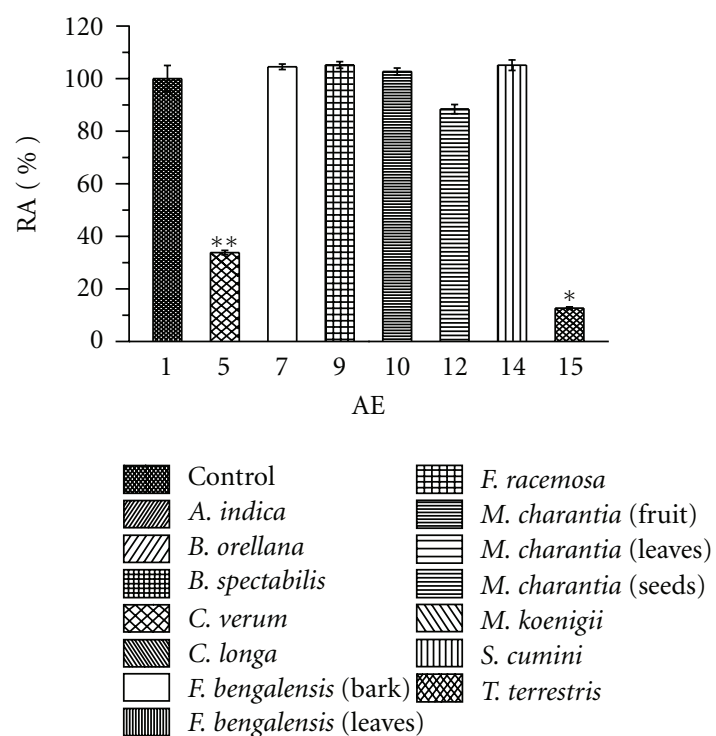

(e)

Figure 1: The percent relative enzyme activity (RA \%) of porcine pancreatic $\alpha$-amylase (PPA) on inhibition with different extracts. (a) Cold-water extracts (CWE). (b) Hot-water extracts (HWE). (c) Methanol extracts (ME). (d) Isopropanol extracts (IP). (e) Acetone extracts (AE) of the listed plants. Pure porcine pancreatic $\alpha$-amylase serves as control. The data is indicated as the mean \pm SEM; $(n=3)$. The students $F$-test was used and the bars with different asterisks $(* * *, * *, *)$ show significant difference with respect to control $(P<.05)$.

independent inhibition for HPA. A preliminary study for the probable mode of inhibition was performed using MichaelisMenten kinetics at their $\mathrm{IC}_{50}$ value with varying substrate concentrations. The double reciprocal Lineweaver-Burk plot showed a decrease in both $V_{\max }$ and $K_{\mathrm{m}}$ values for all the 4 extracts studied, thereby suggesting an uncompetitive type of inhibition (Figure 4). For control HPA, that is, without inhibitor, using starch as the substrate, the apparent $V_{\max }$ and $K_{\mathrm{m}}$ values of $0.17 \mu \mathrm{Mmin}^{-1}, 2.12 \mathrm{mg}$, respectively, were obtained. These kinetic parameters decreased to $0.08 \mu \mathrm{Mmin}^{-1}$ and $1.36 \mathrm{mg}$ for B. orellana, $0.10 \mu \mathrm{Mmin}^{-1}$ and $1.61 \mathrm{mg}$ for C. longa, $0.07 \mu \mathrm{Mmin}^{-1}$ and $1.02 \mathrm{mg}$ for 


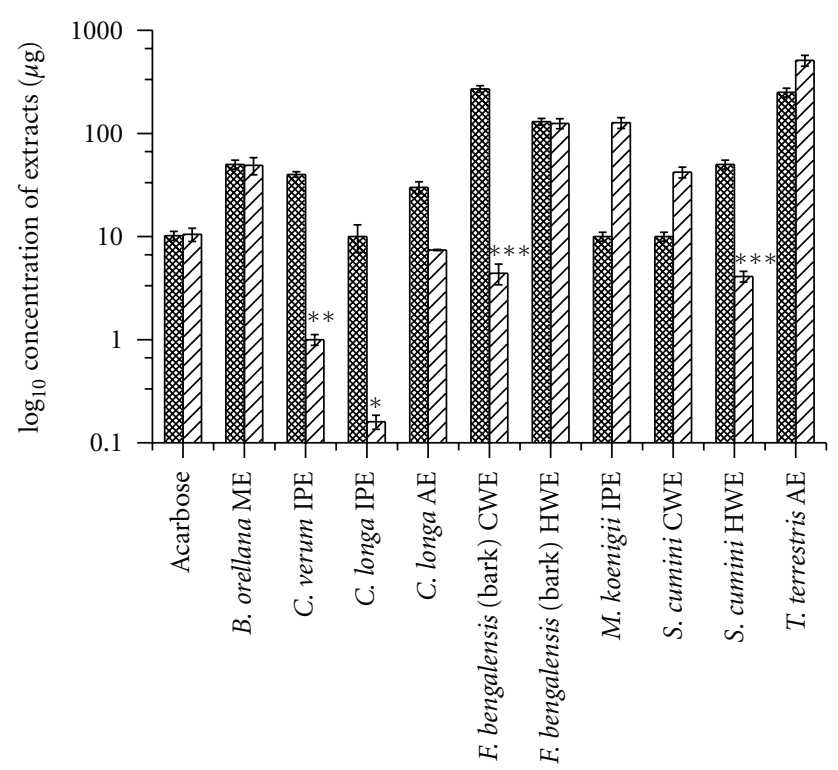

Porcine pancreatic $\alpha$-amylase WIA Human pancreatic $\alpha$-amylase

Figure 2: $\mathrm{IC}_{50}$ values of the extracts exhibiting $\geq 50 \%$ inhibition on Porcine pancreatic $\alpha$-amylase and Human pancreatic $\alpha$-amylase enzyme activity. The data is calculated as the mean $\pm \mathrm{SEM}$; $(n$ $=3$ ). The students F-test was used and the bars with different asterisks $(* * *, * *, *)$ show significant difference with respect to control $(\mathrm{P}<.05)$. Acarbose is taken as the standard $\alpha$-amylase inhibitor.

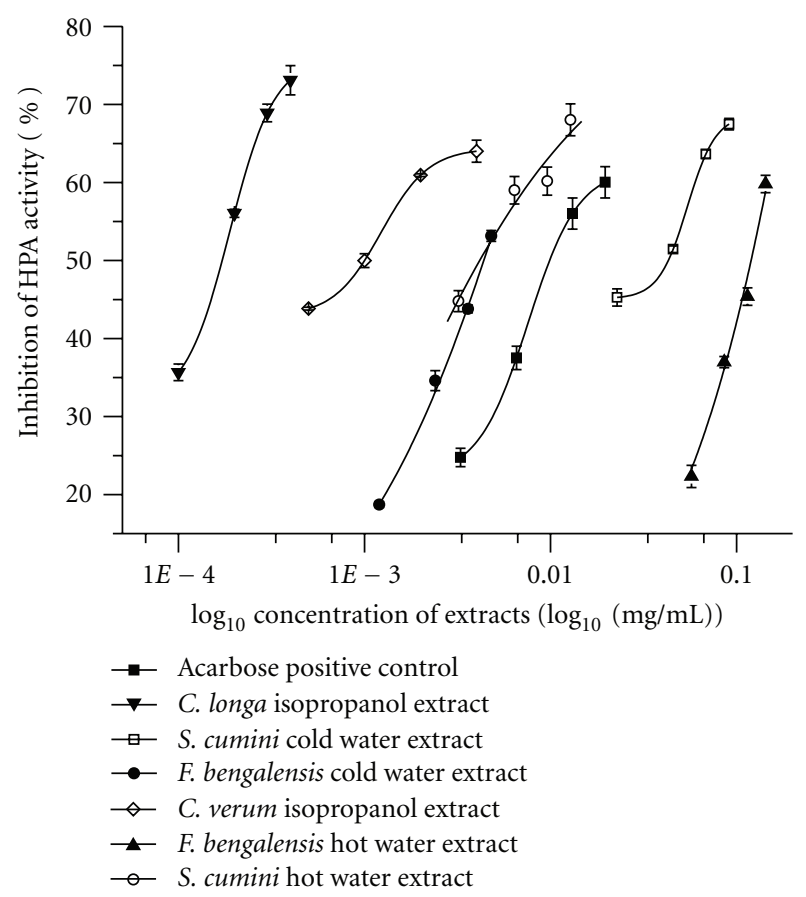

Figure 3: Human Pancreatic $\alpha$-amylase inhibition (\%) of different extracts at varying concentrations. The data is indicated as the mean \pm SEM; $(n=3) .(P<.05)$.

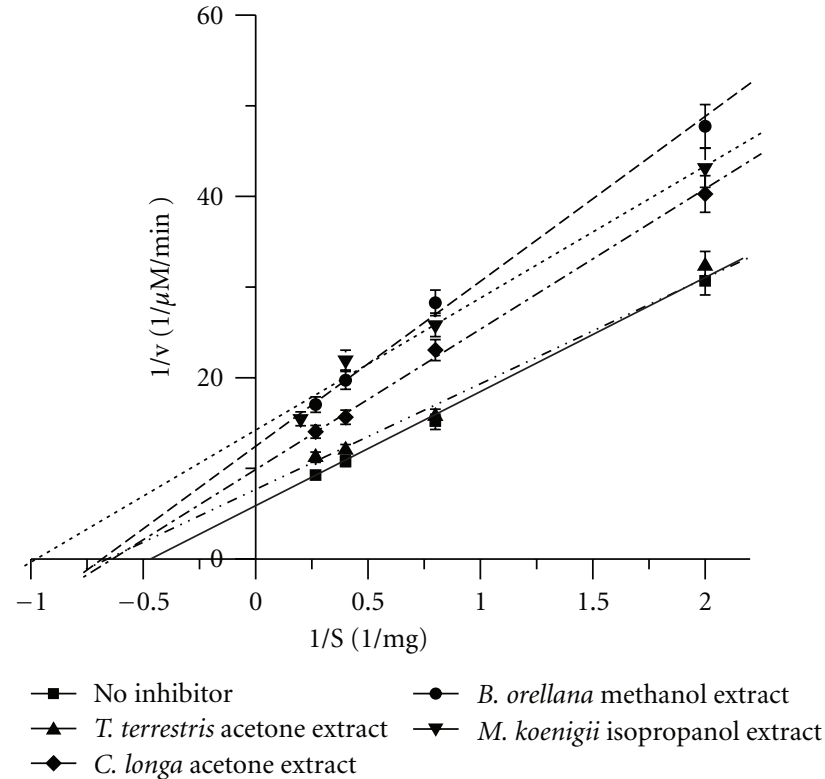

FIGURE 4: Lineweaver-Burk Plot of extracts exhibiting concentration independent inhibition on Human pancreatic $\alpha$-amylase enzyme activity. The data is indicated as the mean \pm SEM; $(n=3)$; $(P<.05)$.

M. koenigii, and $0.14 \mu \mathrm{Mmin}^{-1}$ and $1.71 \mathrm{mg}$ for T. terrestris, respectively.

3.4. Phytochemical and GC-MS Analysis. Preliminary qualitative phytochemical analysis was performed to determine the probable type of compounds present in the extracts causing HPA inhibition. The results showed the presence of different types of active constituents such as proteins, cardiac glycosides, saponins, alkaloids, flavonoids, and so forth. (Table 2).

Using the Wiley-NIST library, GC-MS identification of the compounds based on the retention time, peak area, molecular mass, and molecular formula are shown in Table 3.

\section{Discussion}

The aim of the present study was to investigate the HPA inhibitory activity from medicinal plants known in the Indian Ayurvedic system for their anti-diabetic properties. To date no reports of compounds responsible for HPA inhibition from these plants exist in the literature and we report here for the first time their inhibitory on HPA. Many of the plants chosen in this study are used by the Indian population not only for food purposes but also form a part of the local pharmacopoeia for the treatment of diabetes. Our results indicate that retardation of starch hydrolysis by inhibition of HPA activity by some of these extracts leads to a reduction in glucose concentrations (Figure 5). Of the 11 plants and their 91 extracts tested, 10 exhibited significant inhibition of HPA, suggesting that they contain compounds capable of HPA inhibition. Of these, 4 are aqueous extracts while 6 
TABLe 2: Qualitative phytochemical analysis of the extracts exhibiting $\geq 50 \%$ inhibition on PPA and HPA enzyme activity.

\begin{tabular}{|c|c|c|c|c|c|c|c|}
\hline Plant species & Alkaloids & Proteins & Tannins & Cardiac glycosides & Flavonoids & Saponins & Steroids \\
\hline $\begin{array}{l}\text { B. orellana } L \text {. } \\
(\mathrm{ME})\end{array}$ & - & + & + & + & - & + & + \\
\hline $\begin{array}{l}\text { C. verum } \\
\text { J. S. Presl (IPE) }\end{array}$ & + & + & + & + & - & + & + \\
\hline $\begin{array}{l}\text { C. longa L. } \\
\text { (IPE) }\end{array}$ & + & - & + & - & + & + & + \\
\hline $\begin{array}{l}\text { C. longa L. } \\
\text { (AE) }\end{array}$ & + & - & + & - & + & - & + \\
\hline $\begin{array}{l}\text { F. bengalensis L. } \\
\text { (CWE) }\end{array}$ & + & + & + & - & + & + & - \\
\hline $\begin{array}{l}\text { F. bengalensis L. } \\
\text { (HWE) }\end{array}$ & + & + & - & - & + & + & - \\
\hline $\begin{array}{l}\text { M. koenigii L. } \\
\text { Spreng (IPE) }\end{array}$ & + & - & + & + & - & + & + \\
\hline $\begin{array}{l}\text { S. cumini L. } \\
\text { Skeels. (CWE) }\end{array}$ & + & + & + & - & + & + & - \\
\hline $\begin{array}{l}\text { S. cumini L. } \\
\text { Skeels. (HWE) }\end{array}$ & + & + & + & - & + & + & - \\
\hline $\begin{array}{l}\text { T. terrestris L. } \\
\text { (AE) }\end{array}$ & + & - & - & - & + & + & - \\
\hline
\end{tabular}

+: Detected; -: Not detected; CWE: Cold-water extract; HWE: Hot-water extract; ME: Methanol extract; IPE: Isopropanol extract; AE: Acetone extract.

TABLE 3: GCMS identification of compounds in organic solvent extracts of plants inhibiting HPA enzyme activity.

\begin{tabular}{|c|c|c|c|c|c|}
\hline Plant & Name of the compound & Molecular formula & Molecular weight & Area $\%$ & Retention time (min) \\
\hline \multirow{2}{*}{$\begin{array}{l}\text { B. orellana } L \text {. } \\
\text { (ME) }\end{array}$} & $\beta$-tocopherol & $\mathrm{C}_{28} \mathrm{H}_{48} \mathrm{O}_{2}$ & 416 & 38.85 & 24.29 \\
\hline & Vitamin E & $\mathrm{C}_{29} \mathrm{H}_{50} \mathrm{O}_{2}$ & 430 & 50.17 & 25.96 \\
\hline C. verum & $\begin{array}{l}\text { Naphthalene,1,2,3,4- } \\
\text { tetrahydro-1,1,6-trimethyl }\end{array}$ & $\mathrm{C}_{13} \mathrm{H}_{18}$ & 174 & 32.20 & 6.29 \\
\hline \multirow[t]{2}{*}{ J. S. Presl (IPE) } & Eugenol & $\mathrm{C}_{10} \mathrm{H}_{12} \mathrm{O}_{2}$ & 164 & 2.57 & 11.13 \\
\hline & 4-acetoxycinnamic acid & $\mathrm{C}_{11} \mathrm{H}_{10} \mathrm{O}_{4}$ & 206 & 47.02 & 12.55 \\
\hline \multirow{3}{*}{$\begin{array}{l}\text { C. longa } L \text {. } \\
\text { (IPE) }\end{array}$} & Podocarpic acid & $\mathrm{C}_{17} \mathrm{H}_{22} \mathrm{O}_{3}$ & 274 & 48.21 & 13.69 \\
\hline & Curlone & $\mathrm{C}_{15} \mathrm{H}_{22} \mathrm{O}$ & 218 & 19.53 & 13.95 \\
\hline & Cinnamic-acid & $\mathrm{C}_{9} \mathrm{H}_{8} \mathrm{O}_{2}$ & 148 & 7.03 & 14.79 \\
\hline C. longa $L$. & $\begin{array}{l}\text { 3-Cyano-7-hydroxy-4- } \\
\text { methylcoumarin }\end{array}$ & $\mathrm{C}_{11} \mathrm{H}_{7} \mathrm{NO}_{3}$ & 201 & 42.95 & 13.66 \\
\hline \multirow[t]{2}{*}{$(\mathrm{AE})$} & Curlone & $\mathrm{C}_{15} \mathrm{H}_{22} \mathrm{O}$ & 218 & 17.19 & 13.97 \\
\hline & $\begin{array}{l}\text { 5-amino-2-hydroxybenzoic } \\
\text { acid }\end{array}$ & $\mathrm{C}_{7} \mathrm{H}_{7} \mathrm{NO}_{3}$ & 153 & 9.574 & 17.82 \\
\hline M. koenigii $L$. & $\begin{array}{l}\text { Cyclohexanone, 2-methyl- } \\
\text { 5-(1-methylethenyl)- }\end{array}$ & $\mathrm{C}_{10} \mathrm{H}_{16} \mathrm{O}$ & 152 & 18.54 & 14.8 \\
\hline \multirow[t]{2}{*}{ Spreng (IPE) } & $\begin{array}{l}2,3,5,6- \\
\text { tetrachlorohydroquinone }\end{array}$ & $\mathrm{C}_{6} \mathrm{H}_{2} \mathrm{Cl}_{4} \mathrm{O}_{2}$ & 247 & 51.85 & 24.21 \\
\hline & Vitamin E & $\mathrm{C}_{29} \mathrm{H}_{50} \mathrm{O}_{2}$ & 430 & 10.56 & 25.94 \\
\hline \multirow{2}{*}{$\begin{array}{l}\text { T. terrestris } L \text {. } \\
\text { (AE) }\end{array}$} & Sorbinose & $\mathrm{C}_{6} \mathrm{H}_{12} \mathrm{O}_{6}$ & 180 & 10.27 & 14.27 \\
\hline & Ethyl crotonate & $\mathrm{C}_{6} \mathrm{H}_{10} \mathrm{O}_{2}$ & 114 & 71.36 & 16.96 \\
\hline
\end{tabular}

ME: Methanol extract; IPE: Isopropanol extract; AE: Acetone extract. 


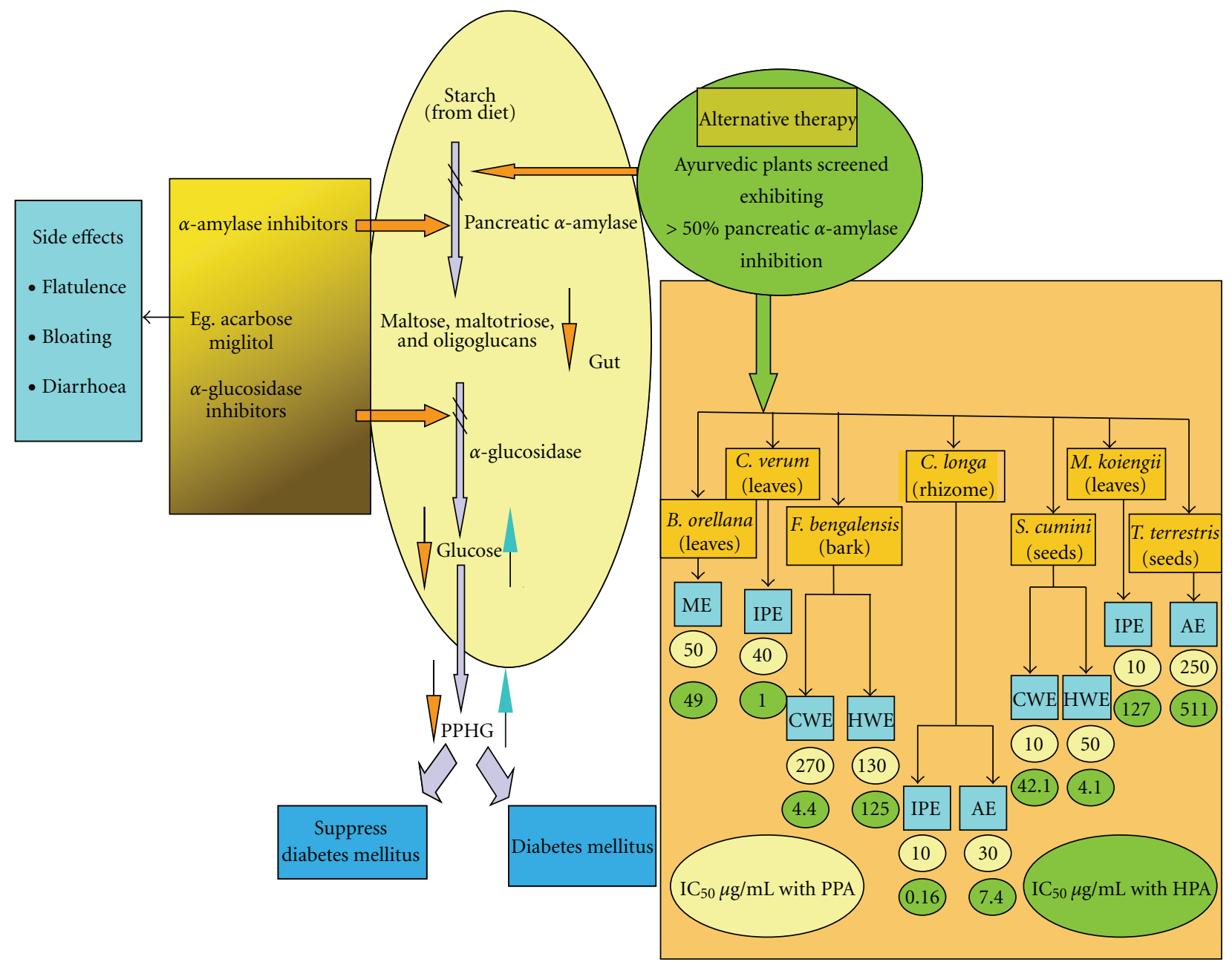

Figure 5: Pancreatic $\alpha$-amylase inhibition by Indian medicinal plant extracts as a potential antidiabetes mechanism. Double bar marks ( $\backslash \backslash$ ) indicate inhibition of amylase activity leading to a reduction of maltose, oligosaccharide and glucose concentration. ME: Methanol extract; AE: Acetone extract; IPE: Isopropanol extract; CWE: Cold-water extract; HWE: Hot-water extract.

are extracts of less-polar solvents. Preliminary phytochemical analysis to indicate the kind of compounds present in these extracts suggests the occurrence of proteins/peptides and polyphenols in cold-and hot-water extracts while tannins, alkaloids, flavonoids, and saponins are found in non-polar extracts. Flavonoids and polyphenolics have been reported to contribute to hypoglycemic activity [30].

B. orellana methanol extract exhibited concentration independent inhibition with an $\mathrm{IC}_{50}$ value of $49 \mu \mathrm{gmL}^{-1}$. The major components identified in this extract were found to be $\beta$-tocopherols and vitamin $\mathrm{E}$ which are known to be present in B. ornella leaves [31].

C. verum inhibited HPA in a concentration-dependent manner with a low $\mathrm{IC}_{50}$ value of $1.0 \mu \mathrm{gmL}^{-1}$. The major components identified were naphthalene, 1, 2, 3, 4-tetrahydro1, 1, 6-trimethyl, eugenol, and 4-acetoxycinnamic acid and have been previously reported $[32,33]$.

C. longa is known to contain curcuminoids, glycosides, terpenoids, and flavonoids [34]. Maximal inhibition of the enzyme (HPA) was obtained with C. longa isopropanol extract at a low concentration of $0.16 \mu \mathrm{gmL}^{-1}$ in a competitive manner and with acetone extract at $7.4 \mu \mathrm{gmL}^{-1}$ in a concentration independent manner. The probable compounds in C. longa isopropanol extract were podocarpic acid, curlone, and cinnamic acid while those in acetone extract were curlone, 3-cyano-7-hydroxy-4-methylcoumarin, and 5amino-2-hydroxybenzoic acid.

F. bengalensis bark extract showed HPA inhibitory activity in the aqueous fraction with an $\mathrm{IC}_{50}$ value of $4.4 \mu \mathrm{gmL}^{-1}$ in a concentration-dependent manner. The major phytochemical components in the aqueous extract were found to be alkaloids, proteins, tannins, flavonoids, and saponins while cardiac glycosides and steroids were found to be absent. A dimethoxy derivative of leucocyanidin 3-Obeta-D-galactosyl cellobioside isolated from the bark of $F$. bengalensis Linn. has been shown to decrease blood sugar levels significantly both in normal and moderately diabetic rats [35].

The compounds identified in $M$. koenigii isopropanol extract were cyclohexanone 2-methyl-5-(1-methylethenyl), 
2, 3, 5, 6 tetrachlorohydroquinone, and Vitamin E which have been reported in leaves by other investigators [36, 37]. The extract was able to inhibit HPA in a concentration independent manner with an $\mathrm{IC}_{50}$ value of $127 \mu \mathrm{gmL}^{-1}$. Kinetic analysis also indicated that this extract resulted in the best decrease in both $K_{\mathrm{m}}$ and $V_{\max }$ values to $1.02 \mathrm{mg}$ and $0.07 \mu \mathrm{Mmin}^{-1}$ as compared to control, namely, $2.12 \mathrm{mg}$ and $0.17 \mu \mathrm{Mmin}^{-1}$.

S. cumini is known to contain proteins, tannins, an alkaloid jambosine, a glycoside antimellin, and fatty acids [38]. The extracts exhibiting concentration-dependent HPA inhibitory activity were cold-and hot-water extracts with an $\mathrm{IC}_{50}$ value of 42.1 and $4.1 \mu \mathrm{gmL}^{-1}$, respectively. It is most likely that the bioactive component could probably be a protein, a glycoside, or a polyphenol.

Furostanol and spirostanol saponins, flavonoids, alkaloids, steroids, carbohydrates, and amides have been isolated from T. terrestris [39]. In our study, the acetone extractinhibited HPA activity in a concentration independent manner with a high $\mathrm{IC}_{50}$ value of $511 \mu \mathrm{gmL}^{-1}$. The compounds identified in this extract were ethyl crotonate and sorbinose.

These findings suggest that inhibition of HPA activity, leading to retardation of starch hydrolysis is one of the mechanisms through which the plants tested in this study could be exhibiting their hypoglycemic effect. Modulation of HPA activity by compounds in these extracts would thus eventually lead to a lowering of post-prandial blood glucose levels (Figure 5). Presence of HPA inhibitor blocks the normal pathway of conversion of dietary starch to maltose, maltotriose, and oligosaccharides and then to glucose in the gut which gets absorbed in the blood. Thus, glucose formation can be blocked in hyperglycemic conditions with pancreatic $\alpha$-amylase inhibitors. This HPA inhibition could occur in a concentration dependent or independent manner depending upon the bioactive compound. The compounds/bioactive principle from these plants responsible for the HPA inhibition need to be isolated and characterized. The efficacy of HPA inhibition can be increased with the combination of these isolated components as shown by Said et al., where in herbal combination of four plants is more effective as antidiabetic traditional medicine [40].

\section{Conclusions}

This study highlights the HPA inhibitory activity of 10 plant extracts exhibiting promising leads as HPA inhibitory molecules and lends scientific support to their use in traditional Ayurvedic medicine. B. orellana, F. bengalensis, S. cumini, C. verum, M. koenigii, C. longa, and T. terrestris plants, which are known for their hypoglycemic property, were found to exhibit strong inhibitory action on HPA, even better than acarbose. The phytochemicals in the extracts causing this inhibition were identified as alkaloids, proteins, tannins, cardiac glycosides, flavonoids, saponins, and steroids. Studies to isolate the bioactive principle(s) from these extracts are required. In the recent years, the search for new molecules as potential $\alpha$-amylase inhibitors with a high specific affinity has intensified. Thus, modulation of
HPA activity through the therapeutic use of high-affinity plant derived inhibitors would be of considerable medical relevance in the treatment of diabetes.

\section{Acknowledgments}

The authors thank the Botany Department, University of Pune, for their help in procuring the plant samples and the Botanical Survey of India (BSI), Pune, for authentication of the collected plant samples. The work was supported by University Grants Commission (UGC), New Delhi. S. Ponnusamy was the recipient of financial aid provided by UGC.

\section{References}

[1] K. G. Alberti and P. Z. Zimmet, "Definition, diagnosis and classification of diabetes mellitus and its complications. Part 1: diagnosis and classification of diabetes mellitus. Report of a WHO Consultation," Diabetic Medicine, vol. 15, no. 7, pp. 539-53, 1998.

[2] World Health Organization (WHO), Diabetes Programme, 2006, http//www.who.Int/diabetes/en/.

[3] H. G. Eichler, A. Korn, and S. Gasic, "The effect of a new specific $\alpha$-amylase inhibitor on post-prandial glucose and insulin excursions in normal and Type 2 (non-insulindependent) diabetic patients," Diabetologia, vol. 26, no. 4, pp. 278-281, 1984.

[4] B. Patwardhan, A. D. B. Vaidya, and M. Chorghade, "Ayurveda and natural products drug discovery," Current Science, vol. 86, no. 6, pp. 789-799, 2004.

[5] G. Klein, J. Kim, K. Himmeldirk, Y. Cao, and X. Chen, "Antidiabetes and anti-obesity activity of Lagerstroemia speciosa," Evidence-Based Complementary and Alternative Medicine, vol. 4, no. 4, pp. 401-407, 2007.

[6] J. K. Grover, S. Yadav, and V. Vats, "Medicinal plants of India with anti-diabetic potential," Journal of Ethnopharmacology, vol. 81, no. 1, pp. 81-100, 2002.

[7] P. K. Mukherjee, K. Maiti, K. Mukherjee, and P. J. Houghton, "Leads from Indian medicinal plants with hypoglycemic potentials," Journal of Ethnopharmacology, vol. 106, no. 1, pp. $1-28,2006$.

[8] Z. L. John and L. Luguang, "Ginseng on hyperglycemia: effects and mechanisms," Evidence-Based Complementary and Alternative Medicine, vol. 6, pp. 423-427, 2009.

[9] S. K. Singh, P. K. Rai, D. Jaiswal, and G. Watal, "Evidencebased critical evaluation of glycemic potential of Cynodon dactylon," Evidence-Based Complementary and Alternative Medicine, vol. 5, no. 4, pp. 415-420, 2008.

[10] M. Bhat, S. S. Zinjarde, S. Y. Bhargava, A. Ravikumar, and B. N. Joshi, "Antidiabetic Indian plants: a good source of potent amylase inhibitors," Evidence-Based Complementary and Alternative Medicine. In press.

[11] M. Bhat, S. K. Kothiwale, A. R. Tirmale, S. Y. Bhargava, and B. N. Joshi, "Antidiabetic properties of Azardiracta indica and Bougainvillea spectabilis: in vivo studies in murine diabetes model," Evidence-Based Complementary and Alternative Medicine. In press.

[12] C. A. Tarling, K. Woods, R. Zhang et al., "The search for novel human pancreatic $\alpha$-amylase inhibitors: High-throughput screening of terrestrial and marine natural product extracts," ChemBioChem, vol. 9, no. 3, pp. 433-438, 2008. 
[13] S. B. Sharma, R. Rajpoot, A. Nasir, K. M. Prabhu, and P. S. Murthy, "Ameliorative effect of active principle isolated from seeds of Eugenia jambolana on carbohydrate metabolism in experimental diabetes," Evidence-Based Complementary and Alternative Medicine. In press.

[14] H. Ali, P. J. Houghton, and A. Soumyanath, " $\alpha$-Amylase inhibitory activity of some Malaysian plants used to treat diabetes; with particular reference to Phyllanthus amarus," Journal of Ethnopharmacology, vol. 107, no. 3, pp. 449-455, 2006.

[15] M. I. Kotowaroo, M. F. Mahomoodally, A. Gurib-Fakim, and A. H. Subratty, "Screening of traditional antidiabetic medicinal plants of Mauritius for possible $\alpha$-amylase inhibitory effects in vitro," Phytotherapy Research, vol. 20, no. 3, pp. 228$231,2006$.

[16] I. Kostova and D. Dinchev, "Saponins in Tribulus terrestrischemistry and bioactivity," Phytochemistry Reviews, vol. 4, no. 2-3, pp. 111-137, 2005.

[17] M. Modak, P. Dixit, J. Londhe, S. Ghaskadbi, and T. P. A. Devasagayam, "Indian herbs and herbal drugs used for the treatment of diabetes," Journal of Clinical Biochemistry and Nutrition, vol. 40, no. 3, pp. 163-173, 2007.

[18] R. R. Chattopadhyay, "Possible mechanism of antihyperglycemic effect of Azadirachta indica leaf extract: part V," Journal of Ethnopharmacology, vol. 67, no. 3, pp. 373-376, 1999.

[19] K. R. M. Russell, E. Y. St. A. Morrison, and D. Ragoobirsingh, "The effect of annatto on insulin binding properties in the dog," Phytotherapy Research, vol. 19, no. 5, pp. 433-436, 2005.

[20] C. R. Narayanan, D. D. Joshi, A. M. Mujumdar, and V. V. Dhekne, "Pinitol—a new anti-diabetic compound from the leaves of Bougainvillea spectabilis," Current Science, vol. 56, pp. 139-141, 1987.

[21] A. Khan, M. Safdar, M. M. A. Khan, K. N. Khattak, and R. A. Anderson, "Cinnamon improves glucose and lipids of people with type 2 diabetes," Diabetes Care, vol. 26, no. 12, pp. 3215-3218, 2003.

[22] N. Arun and N. Nalini, "Efficacy of turmeric on blood sugar and polyol pathway in diabetic albino rats," Plant Foods for Human Nutrition, vol. 57, no. 1, pp. 41-52, 2002.

[23] S. Achrekar, G. S. Kaklij, M. S. Pote, and S. M. Kelkar, "Hypoglycemic activity of Eugenia jambolana and Ficus bengalensis: mechanism of action," In Vivo, vol. 5, no. 2, pp. 143-147, 1991.

[24] P. M. Paarakh, "Ficus racemosa linn.-—an overview," Natural Product Radiance, vol. 8, no. 1, pp. 84-90, 2009.

[25] B. A. Shibib, L. A. Khan, and R. Rahman, "Hypoglycaemic activity of Coccinia indica and Momordica charantia in diabetic rats: depression of the hepatic gluconeogenic enzymes glucose-6-phosphatase and fructose-1,6-bisphosphatase and elevation of both liver and red-cell shunt enzyme glucose-6phosphate dehydrogenase," Biochemical Journal, vol. 292, no. 1, pp. 267-270, 1993.

[26] B. A. Khan, A. Abraham, and S. Leelamma, "Hypoglycemic action of Murraya koenigii (curry leaf) and Brassica juncea (mustard): mechanism of action," Indian Journal of Biochemistry and Biophysics, vol. 32, no. 2, pp. 106-108, 1995.

[27] R. Bajwa, S. Shafique, and S. Shafique, "Fungitoxicity of aqueous and solvent extracts of Datura metel against Ascochyta rabiei," Mycopath, vol. 6, no. 1\&2, pp. 17-22, 2008.

[28] G. L. Miller, "Use of dinitrosalicylic acid reagent for determination of reducing sugar," Analytical Chemistry, vol. 31, no. 3, pp. 426-428, 1959.

[29] J. Parekh and S. V. Chanda, "In vitro antimicrobial activity and phytochemical analysis of some Indian medicinal plants," Turkish Journal of Biology, vol. 31, no. 1, pp. 53-58, 2007.
[30] S. Dewanjee, A. Maiti, R. Sahu, T. K. Dua, and V. Mandal, "Effective control of type 2 diabetes through antioxidant defense by edible fruits of Diospyros peregrine," EvidenceBased Complementary and Alternative Medicine. In press.

[31] T. Barrie and J. Foley, "Tocotrienols and geranylgeraniol from Bixa orellana byproducts," US Patent, 6350453, February 2002.

[32] M. Maridass, "Evaluation of brine shrimp lethality of Cinnamomum Species," Ethnobotanical Leaflets, vol. 12, pp. 772-775, 2008.

[33] Y. Yong and T. Wenyi, "Head-space solid phase microextraction followed by GC/MS analysis of the volatile components in seeds of Cinnamonum camphora," American Journal of Biochemistry and Biotechnology, vol. 1, no. 3, pp. 173-175, 2005.

[34] H. M. Chhetri, N. S. Yogol, J. Sherchan, K. C. Anupa, S. Mansoor, and P. Thapa, "Phytochemical and antimicrobial evaluations of some medicinal plants of Nepal," Katmandu University Journal of Science, Engineering and Technology, vol. 1, pp. 49-54, 2008.

[35] R. V. Kumar and K. T. Augusti, "Antidiabetic effect of a leucocyanidin derivative isolated from the bark of Ficus bengalensis Linn," Indian Journal of Biochemistry and Biophysics, vol. 26, no. 6, pp. 400-404, 1989.

[36] D. Iyer and D. P. Uma, "Plant review: phyto-pharmacology of Murraya koenigii (L.)," Pharmacognosy Reviews, vol. 2, pp. 180-184, 2008.

[37] J. U. Chowdhury and N. I. Bhuiyan, "Chemical composition of the leaf essential oils of Murraya koenigii (L.) Spreng and Murraya paniculata (L.) Jack," Bangladesh Journal of Pharmacology, vol. 3, pp. 59-63, 2008.

[38] I. S. Bhatia and K. L. Bajaj, "Chemical constituents of the seeds and bark of Syzygium cumini," Planta Medica, vol. 28, no. 4, pp. 346-352, 1975.

[39] T.-S. Wu, L.-S. Shi, and S.-C. Kuo, "Alkaloids and other constituents from Tribulus terrestris," Phytochemistry, vol. 50, no. 8, pp. 1411-1415, 1999.

[40] O. Said, S. Fulder, K. Khalil, H. Azaizeh, E. Kassis, and B. Saad, "Maintaining a physiological blood glucose level with 'glucolevel', a combination of four anti-diabetes plants used in the traditional Arab herbal medicine," Evidence-Based Complementary and Alternative Medicine, vol. 5, no. 4, pp. 421-428, 2008. 


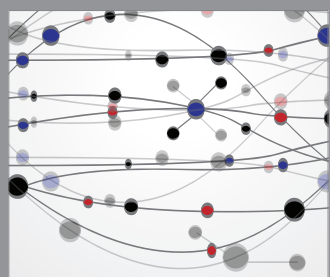

The Scientific World Journal
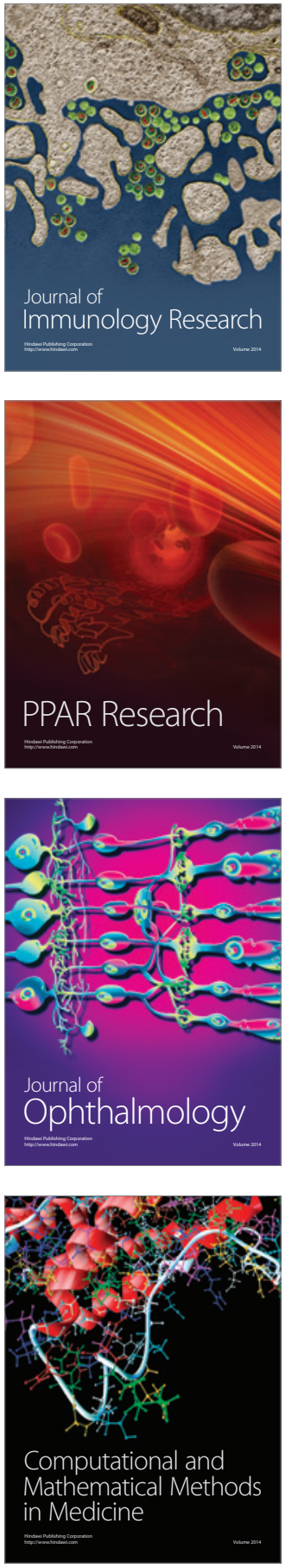

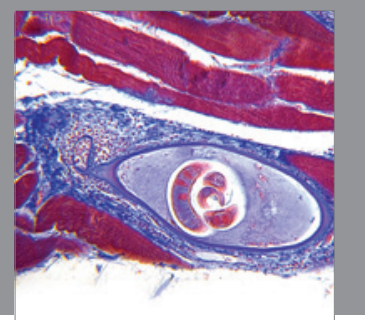

Gastroenterology

Research and Practice
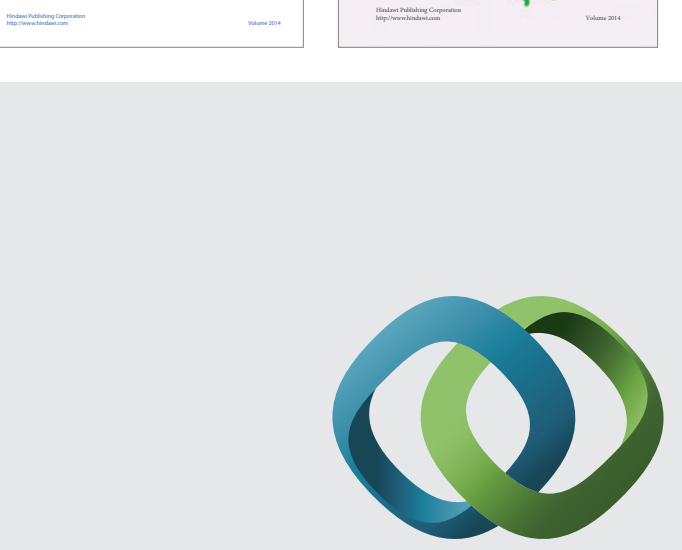

\section{Hindawi}

Submit your manuscripts at

http://www.hindawi.com
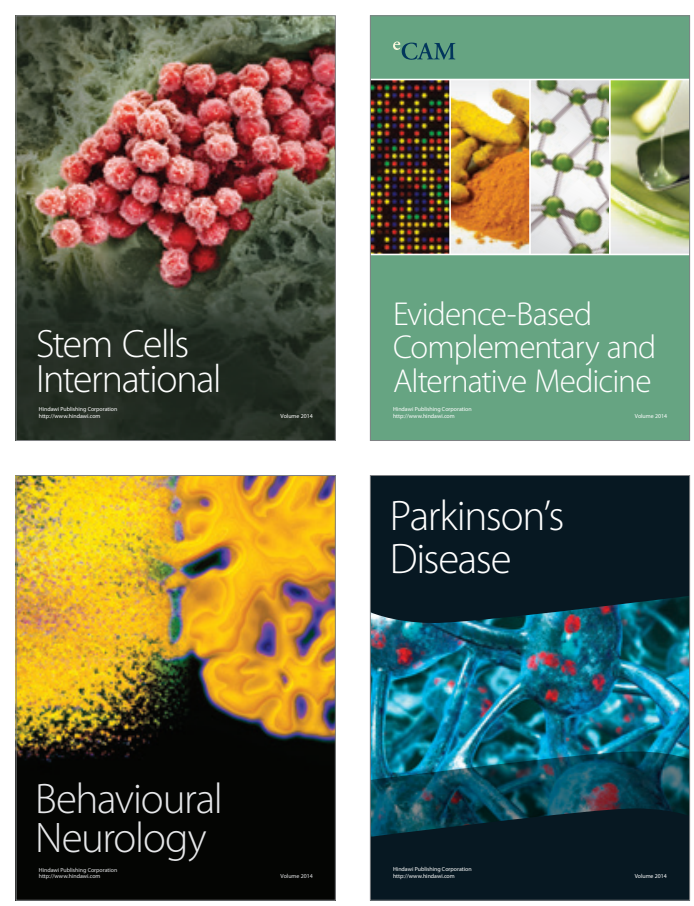

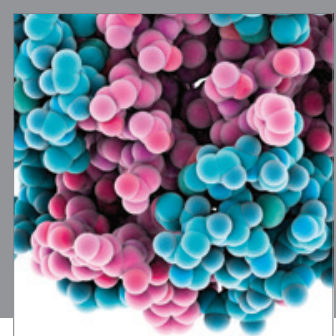

Journal of
Diabetes Research

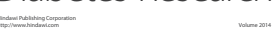

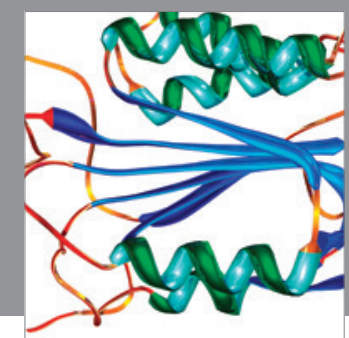

Disease Markers
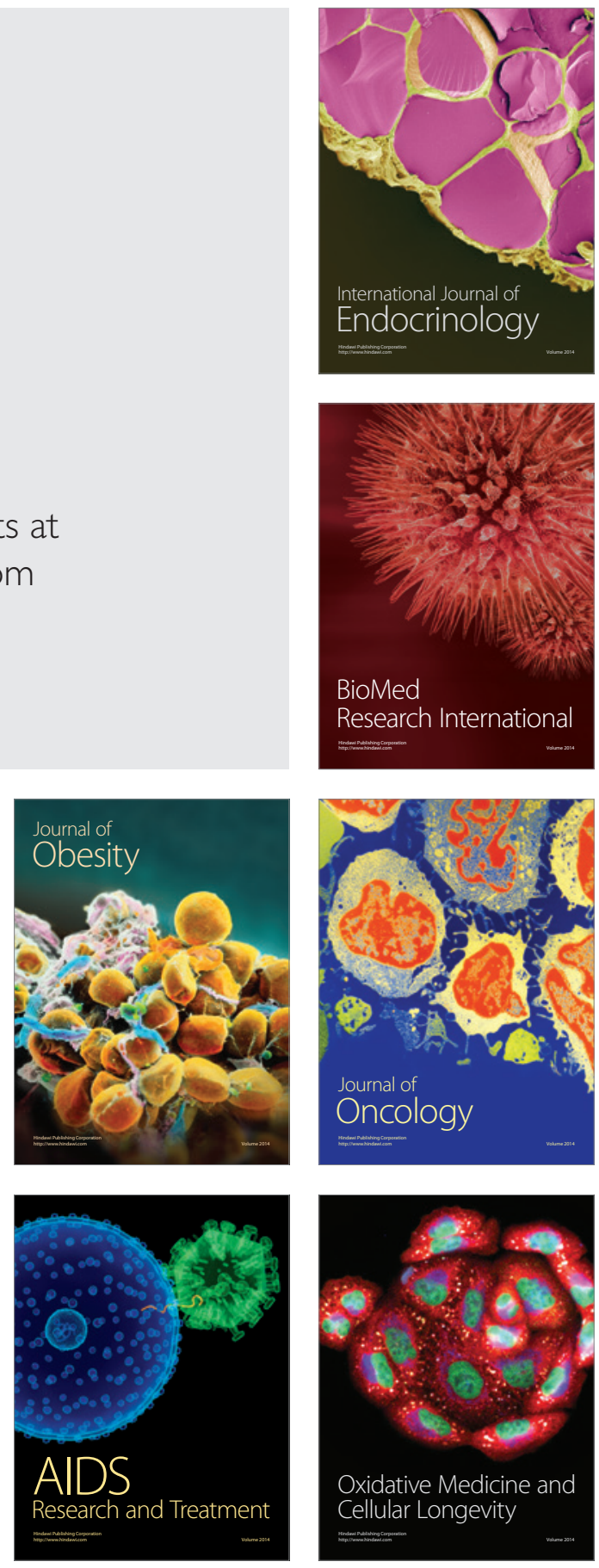